\title{
Management of asthma and allergic rhinitis in children during the COVID-19 pandemic
}

\author{
Andrzej Emeryk', Ewelina Wawryk-Gawda', Kamil Janeczek ${ }^{1}$ \\ ${ }^{1}$ Department of Pulmonary Diseases and Children Rheumatology, Medical University of Lublin \\ Head of Department: prof. Andrzej Emeryk, MD, PhD
}

\begin{abstract}
:
The aim of the study was to present current data on the treatment of children with asthma and allergic rhinitis during the COVID-19 pandemic. To this end, the available literature was reviewed (until 2020, June $1^{\text {st }}$ ).
\end{abstract}

Key words: COVID-19, asthma, allergic rhinitis, children

COVID-19 in children - essential epidemiological and clinical facts

Coronaviruses are a large family (Coronaviridae) of single-stranded RNA viruses which cause disease in humans and animals. They have been known since the 1940s. At first, they were isolated only from animals, then coronaviruses were characterized as an etiological factor of respiratory diseases also in humans [1]. Due to their ability to mutate, new strains of coronavirus pathogenic to both animals and humans are constantly appearing, and the possibility of coronavirus transmission between humans and animals has been observed $[1,2]$. Commonly occurring human coronaviruses - HCoV-229E, HKU1, NL63, OC43 - are responsible for seasonal respiratory tract infections in children, causing exacerbations of chronic respiratory diseases such as asthma. Among animals, coronaviruses are most often isolated from bats, camels, cattle, poultry, pigs and cats $[3,4]$. These viruses were not a serious epidemiological problem for many years. Due to the constant discovery of new coronaviruses, they have been divided into four types: alpha, beta, gamma, and delta, of which the first two occur in humans. Research on coronaviruses intensified after the appear- ance of $\beta$-coronaviruses dangerous to humans at the beginning of the $21^{\text {st }}$ century. In 2002, a virus called SARS-CoV (severe acute respiratory syndrome associated coronavirus), a type of $\beta$-coronavirus, caused severe lower respiratory tract infections initially in China (in the Guangdong province), then spreading to other countries and causing the death of 774 people. Another beta-type virus is MERS-CoV (middle east respiratory syndrome coronavirus), which appeared in Saudi Arabia in 2012, and then spread to 27 countries, causing the death of 858 people and is occasionally still found in isolated cases in Qatar, Bahrain, Jordan, Kuwait, and Tunisia [3-5].

Identified in December 2019 in China, SARS-CoV-2, which also belongs to the $\beta$-coronavirus genus, has become an unmanageable global problem due to its high infectivity, rapid spread, and extensive symptomatology of the disease it causes.

The disease caused by SARS-CoV-2 is called COVID-19 (coronavirus disease 2019), and its symptoms vary widely. Among COVID-19 patients, children account for about $1-2 \%$ and the course of the disease in the pediatric population is usually mild [6]. COVID-19 has been observed in children of all ages. According to 
Chinese studies, infants accounted for $17.6-18.1 \%$ of sick children, children aged 1-10 years $-47.5-57.3 \%$, children over 10 years of age $-24.6-34.9 \%$ [7, 8]. In other countries, however, more frequent cases have been observed in older children. In Iceland, among a group of 564 children under 10 years of age, a positive test result was obtained in $6.7 \%$, and in a group of 8635 children over 10 years of age, a positive test result was obtained by $13.7 \%$ of children [9]. In an American study, children under 10 years of age constituted $41 \%$ of all sick children [10].

Data from most countries confirm that boys are slightly more often ill $(56.6 \%)$ than girls $[7,10-12]$. Infected children can be asymptomatic (up to $30 \%$ ), or experience mild (about 51\%), moderate (about 38\%) or severe (about $6 \%$ ) symptoms. Clinical symptoms in most patients increase rapidly and are pronounced. The younger the child, the greater the risk of a more severe course of COVID-19, which is likely associated with the immature and less effective immune response to the infection, narrower airways, and the predisposition for severe bronchiolitis in this age group [8, 13].

Data from the two largest pediatric studies conducted in China on a group of children with confirmed or suspected SARS-CoV-2 infection indicate that the most common symptoms are cough, usually dry (48\% of children), redness of the throat ( $46 \%$ of children), increased heart rate (in 42\%) and body temperature above $37.5^{\circ} \mathrm{C}$ ( $41 \%$ of children). A fever above $38^{\circ} \mathrm{C}$ occurs relatively rarely in children (in $32 \%$ ), as does tachypnoe (in 29\%). Other, less common symptoms in the early stages of the disease are diarrhea $(9 \%)$, fatigue $(8 \%)$, a runny nose (8\%) and vomiting $(6 \%)$ [8, $14,15]$. In addition, in France, neurological disorders in the course of COVID-19 were observed in infants under 3 months of age [16].

Pneumonia confirmed by radiological examination was observed in some children during COVID-19 $[7,8,14,15]$. Among children hospitalized in Wuhan, lung consolidations were observed in approximately $65 \%$ of children [8]. In Madrid, among 41 children with a positive SARS-CoV-2 result, pneumonia was found in 20\% [14]. Among 4 children from Malaysia aged from 20 months to 9 years, radiological changes in the lungs in the form of perihilar infiltrations were found in 2 children [17]. The authors emphasize that radiographic changes (both one- and two-sided) in the lungs also occur in children with no signs of lower respiratory tract infection [17]. In the vast majority of cases, the course of the disease in children is mild. They usually do not require hospitalization. A few studies have described cases of children requiring hos- pital treatment or intensive care in the form of respiratory support and dialysis $[18,19]$. Deaths most often affect children with other diseases. In Wuhan, a child who had intussusception simultaneously with COVID-19 died [8]. In the USA, by April $2^{\text {nd }}$, three children out of 2572 infected with SARS-CoV-2 died [10, 20].

The vast majority of infected children recover after 1-2 weeks after the first symptoms. It is difficult to determine the infectivity period of patients. The virus was found in the nasopharynx secretions of patients for an average of 12 days from the beginning of the disease, while in stool samples the virus was found to last up to 30 days $[11,21]$. Correct decontamination of the surfaces of rooms in which patients with COVID-19 were staying and the use of personal protective equipment allowed to eliminate the virus and thus protect the personnel against infection $[22,23]$.

\section{SARS-CoV-2 and asthma}

Asthma as one of the chronic inflammatory diseases of the respiratory system was initially considered to be a risk factor contributing to severe COVID-19 [24]. It resulted from many years of observation of asthma exacerbations in the course of viral respiratory tract infections, including those caused by coronaviruses [25]. In addition, increased levels of proinflammatory cytokines were found in COVID-19 patients, which play an important role in the pathogenesis of asthma [26-30]. However, data from authors from several countries shows that asthma is not associated with a greater susceptibility to SARS-CoV-2 infection or a more severe course of COVID-19 [31]. The number of patients with asthma among those infected with SARS-CoV-2 and the severity of the infection are similar to the general population. In addition, it was found that people with inhaled allergies have reduced expression of the ACE2 receptor (angiotensin-converting enzyme-2), which presumably reduces the susceptibility to SARS-CoV-2 infection [12, 31-34].

Due to the low incidence of children with COVID-19, there is no detailed data on the course of asthma in this group of patients. Only single cases of children with asthma infected with SARS-CoV-2 have been reported [14, 25, 26].

\section{Diagnosis and monitoring of asthma and allergic rhinitis during the SARS-CoV-2 pandemic}

Experts of the Polish Society of Allergology (PTA) rightly point out the need to limit the performance of certain allergological procedures during the 
coronavirus pandemic, recommending that they be carried out only in exceptional situations. These are: skin prick tests (SPT), intradermal tests, patch tests with contact allergens, spirometry, PEF measurement in the doctor's office, measurement of nitric oxide in exhaled air, non-specific and specific bronchial and nasal provocation tests (inhalant allergens), and food allergen or drug provocation tests. In the case of indications for IgE-dependent sensitization, it is recommended to carry out in vitro tests to detect the presence of specific IgE (sIgE) instead of SPT [35-37].

\section{Asthma therapy during the SARS-CoV-2 pandemic}

Inhaled corticosteroids (ICS) are the basis for chronic asthma treatment and during the SARS-CoV-2 epidemic should be used in both uninfected and coronavirus infected patients with asthma according to generally accepted standards (tab. 1, 2) [38, 39].

There are no indications that ICS may increase the susceptibility to SARS-CoV-2 infections or affect COVID-19. On the contrary, experience with respiratory tract infections with other RNA viruses indicates that good asthma control associated with effective ICS treatment reduces the risk of exacerbations associated with these infections $[40,41]$. Therefore, the reduction or withdrawal of ICS may result in a loss of asthma control and, as a result, increase susceptibility to SARS-CoV-2 infection, which is clearly indicated by the recommendations of GINA experts from 2020 [39].

Furthermore, the loss of asthma control may lead to the patient having to be taken to an emergency room (ER) or being hospitalized, which further increases the risk of infection. Optimal asthma treatment is crucial not only for patients, but also for their environment. Incomplete asthma control may manifest itself in more frequent bouts of coughing, which even in the asymptomatic course of COVID-19 in an asthma patient may significantly increase the risk of transmission of the infection to people in the immediate vicinity [36].

Therefore, PTA and GINA experts during the SARS-CoV-2 pandemic recommend:

- continuing ICS anti-inflammatory treatment in patients with asthma

- using inhaled drugs with a pressurised metered dose inhaler (pMDI), pMDI breath-actuated (pMDI-BA) or dry powder inhaler (DPI) in children $>5$ years of age

Table 1. Management of asthma in children aged 6-11 years according to the GINA report 2019 and 2020 [38, 39].

\begin{tabular}{|c|c|c|c|c|}
\hline Step 1 & Step 2 & Step 3 & Step 4 & Step 5 \\
\hline $\begin{array}{l}\text { Preferred controller: } \\
\text { no recommendations }\end{array}$ & $\begin{array}{l}\text { Preferred con- } \\
\text { troller: } \\
\text { daily low dose ICS }\end{array}$ & $\begin{array}{l}\text { Preferred con- } \\
\text { troller: } \\
\text { low dose ICS-LABA } \\
\text { or medium dose } \\
\text { ICS }\end{array}$ & $\begin{array}{l}\text { Preferred controller: } \\
\text { medium dose ICS-LABA (from } \\
\text { one or separate inhalers) and } \\
\text { consider specialist consultation }\end{array}$ & $\begin{array}{l}\text { Preferred controller: } \\
\text { high dose ICS-LABA (from one or sepa- } \\
\text { rate inhalers) and refer for asthma phe- } \\
\text { notypic assessment and consider therapy } \\
\text { with additional drugs such as anti-IgE }\end{array}$ \\
\hline $\begin{array}{l}\text { Other controller } \\
\text { options: } \\
\text { low dose ICS taken } \\
\text { whenever SABA is taken } \\
\text { or daily low dose ICS }\end{array}$ & $\begin{array}{l}\text { Other controller } \\
\text { options: } \\
\text { LTRA or low dose } \\
\text { ICS taken whenev- } \\
\text { er SABA is taken }\end{array}$ & $\begin{array}{l}\text { Other controller } \\
\text { options: } \\
\text { low dose ICS + } \\
\text { LTRA }\end{array}$ & $\begin{array}{l}\text { Other controller options: } \\
\text { high dose ICS-LABA or add-on } \\
\text { tiotropium or add-on LTRA }\end{array}$ & $\begin{array}{l}\text { Other controller options: add-on anti-IL5 } \\
\text { or add-on low dose OCS (but consider } \\
\text { side-effects) }\end{array}$ \\
\hline
\end{tabular}

Education, individual treatment plan, non-pharmacological interventions, therapy of concomitant diseases, tertiary prevention based on the reduction of modifiable risk factors. SMART therapy possible from step 3.

Reliever treatment at all steps: SABA as-needed.

ICS - inhaled corticosteroids; SABA - short-acting $\beta$-agonists; LABA - long-acting $\beta$-agonists; LTRA - leukotriene receptor antagonist; OCS - oral corticosteroids; SMART - single maintenance and reliever therapy.

Table 2. Management of asthma in children aged 0-5 years according to the GINA report 2019 and 2020 [38, 39$].$

\begin{tabular}{|l|l|l|l|}
\hline \multicolumn{1}{|c|}{ Step 1 } & \multicolumn{1}{|c|}{ Step 2 } & \multicolumn{1}{c|}{ Step 3 4} \\
\hline $\begin{array}{l}\text { Preferred controller: } \\
\text { no chronic treatment }\end{array}$ & $\begin{array}{l}\text { Preferred controller: } \\
\text { daily low dose ICS }\end{array}$ & $\begin{array}{l}\text { Preferred controller: } \\
\text { medium dose ICS }\end{array}$ & $\begin{array}{l}\text { Preferred controller: } \\
\text { medium dose ICS and refer to a specialist }\end{array}$ \\
\hline $\begin{array}{l}\text { Other controller options: } \\
\text { consider low dose ICS }\end{array}$ & $\begin{array}{l}\text { Other controller options: } \\
\text { LTRA }\end{array}$ & $\begin{array}{l}\text { Other controller options: } \\
\text { low dose ICS + LTRA }\end{array}$ & $\begin{array}{l}\text { Other controller options: } \\
\text { medium dose ICS + LTRA }\end{array}$ \\
\hline \multicolumn{2}{|l|}{ Reliever treatment at all steps: SABA as-needed. }
\end{tabular}

ICS - inhaled corticosteroids; SABA - short-acting $\beta$-agonists; LTRA - leukotriene receptor antagonist. 
- taking OCS by patients with severe or moderate exacerbation of asthma, which may prevent hospitalization of the child

- starting or continuing anti-IgE ( $>6$ years of age) or anti-IL-5 ( $>18$ years of age) therapy in patients with severe asthma in accordance with current drug programs

- continuing subcutaneous immunotherapy (SCIT) in patients with allergic rhinitis and/or asthma. However, taking into account the epidemiological and organizational aspects, the physician in consultation with the patient may consider temporarily suspending SCIT with the prospect of its resumption in conditions ensuring complete safety. Another possibility is to apply sublingual therapy (SLIT), after consultation with the patient [35, 36, 42-45].

The implementation of a number of recommendations related to different types of aerosol therapy can be problematic in practical application. Shaker et al. and GINA 2020 recommend not using drugs in nebulization (NEB) during the SARS-CoV-2 pandemic, as it may cause increased aerosolization of viral particles in the environment and promote the spread of infection $[35,39]$. The authors of these studies recommend other inhalation methods: pMDI, pMDI-BA or DPI. A large group of children with asthma under 5 years of age and some older children are treated in Poland with the help of NEB, and their parents often do not have drugs with pMDI and valved holding chambers [46, 47]. The position of Polish experts on NEB during the COVID-19 pandemic was developed as a result of a critical analysis of the recommendations contained in GINA 2020 and the PTA position, and based on the latest literature in the field of aerosol therapy [48]. The most important recommendations from this study state that:

1. During the COVID-19 pandemic, inhalation therapy should be used in accordance with current medical indications and dosing rules, including using nebulizers appropriate for the given clinical situation.

2. NEB conducted at home in the absence of household members infected with SARS-CoV-2 seems just as safe during the COVID-19 pandemic as before the pandemic by complying with NEB safety rules. However, it is important to remember to use safeguards (filters, sterilization) to minimize environmental contamination.

3. Replacing NEB with other forms of inhalation therapy (pMDI, DPI) is recommended in patients with COVID-19 who are treated in ER or hospitalized. In outpatient cases with well-controlled asthma or chronic obstructive pulmonary disease, the type of inhaler should not be changed unless there is a significant reason.

4. NEB in the hospital should be carried out only with medicines (and not medical products), and the nebulizer should be equipped with an antibacterial and antiviral filter limiting contamination of the patient's environment.

5. It is important to use nebulizers minimizing the risk of bioaerosol getting into the environment, especially in the hospital.

6. Moreover, it is absolutely necessary to observe the conditions of safe NEB, such as: conducting NEB in a special inhalation room of a hospital ward equipped with exhaust ventilations, complying with the recommended nebulization procedures, securing medical personnel with personal protective equipment, properly sterilized nebulization equipment and rooms where NEB was performed.

7. It is not possible to replace NEB with any other inhalation therapy methods in the case of drugs available only in a nebulization formula (e.g. dornase alfa, some antibiotics).

\section{Management of patients with asthma and COVID-19}

Due to the lack of evidence of an increased risk of severe COVID-19 in patients with asthma, no specific treatment policy has been defined for children with asthma who contract COVID-19 [35, 49]. In the management of patients with asthma and suspected COVID-19, the physician should follow the principles set out in figure 1. For epidemiological reasons, visits of such patients in Family Doctor Clinics and Specialist Clinics should be limited. It is recommended to:

- provide telephone advice or contact by other means of communication to minimize the risk of spreading SARS-CoV-2

- isolate people with other chronic diseases

- shorten the waiting time for medical visits.

The information obtained from the patient during a telephone appointment is decisive in determining what to do next. In cases of increased risk of life-threatening or health emergencies, patients require direct medical attention [35]. Then, during contact with the patient, it is recommended to use the appropriate personal protective equipment, i.e. a mask with an FFP2 or FFP3 filter, a cap, safety glasses and/or a visor, a waterproof long-sleeved apron and at least 2 pairs of gloves. If the performance of activities related to the generation of aerosol is planned, it is recommended to 
carry out examination and treatment in a negative pressure room $[35,49]$.

The therapeutic management of COVID-19 in patients with asthma does not differ from that in patients without asthma (fig. 1). It is not recommended to routinely use antiviral drugs or antibiotics in every patient who is SARS-CoV-2 positive [11]. Antibiotic therapy was applied only in cases of confirmed pneumonia with probable bacterial origin and other bacterial complications $[11,50]$. In the case of co-infection with the influenza virus, oseltamivir was used. Other drugs which have been used in patients hospitalized due to COVID-19 include: interferon- $\alpha$, umifenovir, lopinavir, chloroquine, and specific immunoglobulins $[11,12]$. Clinical trials are being conducted using various antiviral drugs, but their results so far do not constitute a basis for introducing them to the standards of treatment of patients with COVID-19 and asthma.
Lopinavir/ritonavir and remdesivir are among the antiviral medications recommended by the Spanish Pediatric Association for the treatment of patients with severe COVID-19 [13, 17, 35, 50-52] (fig. 2).

\section{COVID-19 and allergic rhinitis}

Most children with IgE-dependent asthma also have allergic rhinitis (AR) requiring appropriate therapeutic management. There is no official data regarding COVID-19 in AR patients so far [53, 54]. During the COVID-19 pandemic, it is necessary to continue the treatment of these patients. Nasal corticosteroids are the most important drugs in the treatment of all forms of AR in children (tab. 3). ARIA (Allergic Rhinitis and its Impact on Asthma) and EAACI (European Academy of Allergy and Clinical Immunology) explicitly recommend continuing AR therapy during the

Figure 1. Management of a patient with asthma exacerbation during the SARS-CoV-2 pandemic [35, 51].

\begin{tabular}{|c|c|}
\hline $\begin{array}{l}\text { High risk of COVID-19 } \\
\text { Low risk of severe asthma } \\
\text { exacerbations }\end{array}$ & $\begin{array}{l}\text { - Performance of the SARS-CoV-2 test } \\
\text { - Assessment of the patient's condition during a telephone appointment }\end{array}$ \\
\hline $\begin{array}{l}\text { High risk of COVID-19 } \\
\text { High risk of severe asthma } \\
\text { exacerbation or not possible to assess }\end{array}$ & $\begin{array}{l}\text { - Performance of the SARS-CoV-2 test } \\
\text { - It is advisable to conduct a direct appointment in the office with the use of personal } \\
\text { protective equipment and in a ventilated room with the use of negative pressure technology } \\
\text { (especially if performing activities resulting in the generation of aerosol is planned) }\end{array}$ \\
\hline $\begin{array}{l}\text { Low risk of COVID-19 } \\
\text { Low risk of severe asthma } \\
\text { exacerbations }\end{array}$ & - Assessment of the patient's condition during a telephone appointment \\
\hline $\begin{array}{l}\text { Low risk of COVID-19 } \\
\text { High risk of severe asthma } \\
\text { exacerbation or not possible to assess }\end{array}$ & $\begin{array}{l}\text { - It is advisable to conduct a direct appointment in the office using personal protective } \\
\text { equipment }\end{array}$ \\
\hline
\end{tabular}

Figure 2. Current methods of treating a child suffering from COVID-19 [17, 18, 35, 49, 51, 52].

- Isolation and rest (use of sedative drugs if stimulated).

- Adequate nutrition and proper hydration of the patient, replenishment of electrolytes.

- Monitoring vital signs (body temperature, saturation, heart rate, glycemia).

- Assessment of blood count, inflammation parameters, coagulation system, biochemical exponents assessing kidney, liver and heart function, lung ultrasound, chest X-ray or ct in the case of suspected pneumonia.

- In the case of fever (over $38.5^{\circ} \mathrm{C}$ ) - physical methods of cooling, use of antipyretic drugs (ibuprofen, paracetamol) in standard doses.

- Prevention of airway obstruction (in the case of shortness of breath using saba or other bronchodilators with pmdi).

- Oxygen therapy in the case of hypoxia, maintaining saturation $>92 \%$.

- Invasive methods of oxygen therapy, ecmo in cases of respiratory failure.

- Renal replacement therapy for renal failure.

- If bacterial or fungal superinfection is suspected, apply antibiotic therapy (intravenous amoxicillin with clavulanic acid as first choice treatment) or antifungal agents.

- The use of oseltamivir in the case of influenza virus infection.

- The use of systemic corticosteroids, inhaled interferon-alpha, and immunoglobulins should be considered individually.

- Drugs such as lopinavir, litonavir, remdesivir, faviravir, nitazoxanide, ivermectin, hydroxychloroquine, chloroquine alone or in combination with azithromycin or clarithromycin are not routinely recommended for COVID-19 treatment; therapy with these drugs is at the stage of clinical trials. 
Table 3. Drugs used in allergic rhinitis therapy and their impact on individual symptoms of the disease $[55,56]$.

\begin{tabular}{|c|c|c|c|c|c|}
\hline Drug group & $\begin{array}{l}\text { Sneez- } \\
\text { ing }\end{array}$ & $\begin{array}{l}\text { Itchy } \\
\text { nose }\end{array}$ & $\begin{array}{l}\text { Watery } \\
\text { discharge }\end{array}$ & $\begin{array}{l}\text { Nose } \\
\text { block }\end{array}$ & $\begin{array}{c}\text { Eye symp- } \\
\text { toms }\end{array}$ \\
\hline $\begin{array}{l}\text { Nasal corticoste- } \\
\text { roids }\end{array}$ & +++ & ++ & +++ & ++ & ++ \\
\hline $\begin{array}{l}\text { Oral corticoste- } \\
\text { roids }\end{array}$ & +++ & ++ & +++ & ++ & +++ \\
\hline $\begin{array}{l}\text { Nasal antihista- } \\
\text { mines }\end{array}$ & ++ & +++ & ++ & + & - \\
\hline $\begin{array}{l}\text { Oral antihista- } \\
\text { mines }\end{array}$ & ++ & +++ & ++ & $+/-$ & ++ \\
\hline Nasal a-mimetics & - & - & - & ++ & - \\
\hline Oral a-mimetics & - & - & - & + & - \\
\hline $\begin{array}{l}\text { Nasal anticholin- } \\
\text { ergics }\end{array}$ & - & - & +++ & - & - \\
\hline $\begin{array}{l}\text { Oral anticholin- } \\
\text { ergics }\end{array}$ & + & + & ++ & t+ & ++ \\
\hline Nasal cromones & $+/-$ & $+/-$ & $+/-$ & $+/-$ & - \\
\hline Saline & $+/-$ & $+/-$ & $+/-$ & - & - \\
\hline
\end{tabular}

COVID-19 pandemic, stressing that the use of nasal corticosteroids does not reduce immunity and does not pose a risk of severe COVID-19. Discontinuation of nasal corticosteroids is not recommended in patients already treated with these drugs. Discontinuation of therapy exposes the patient to an exacerbation of the clinical course of AR and thus easier infection through swollen and congested nasal turbinates and damaged nasal epithelium. Interrupting the treatment of AR patients and those infected with SARS-CoV-2 may result in increased AR symptoms, including sneezing, which in turn is associated with greater spraying of aerosol containing virus particles in the air and easier spreading of the infection. Attention should also paid to the symptoms of conjunctivitis, which often accompany patients with AR, and may also occur in the early COVID-19 period [36, 54]. It is therefore important to consider the risk of SARS-CoV-2 infection, accurately collect an epidemiological history focused on the possibility of contact with a person suffering from COVID-19, as well as to analyze disease symptoms in order to make a proper diagnosis and start appropriate treatment.

\section{References}

1. Pyrć K. SARS-CoV-2. Klinika Nowa. 2020; 27(1): 9-14.

2. Zhang T, Wu Q, Zhang Z. Probable pangolin origin of SARS-CoV-2 associated with the COVID-19 outbreak. Curr Biol. 2020; 30(7): 1346-51.

3. Geller C, Varbanov M, Duval RE. Human coronaviruses: insights into environmental resistance and its influence on the development of new antiseptic strategies. Viruses. 2012; 4(11): 3044-68.

4. Zimmermann P, Curtis N. Coronavirus infections in children including COVID-19: an overview of the epidemiology, clinical features, diagnosis, treatment and prevention options in children. Pediatr Infect Dis J. 2020; 39(5): 355-68.

5. Grzesiowski P. Pandemia COVID-19-epidemiologia, patofizjologia, aspekty kliniczne. Klinika Nowa. 2020; 27(1): 4-8.

6. She J, Liu L, Liu W. COVID-19 epidemic: Disease characteristics in children. J Med Virol. 2020; 92(7): 747-54. http://doi. org/10.1002/jmv.25807.

7. Dong Y, Mo X, Hu Y et al. Epidemiology of COVID-19 among children in China. Pediatrics. 2020; 145(6): e20200702.

8. Lu X, Zhang L, Du H et al. SARS-CoV-2 infection in children. NEngl J Med. 2020; 382(17): 1663-5.

9. Gudbjartsson DF, Helgason A, Jonsson $H$ et al. Spread of SARS-CoV-2 in the Icelandic population. $N$ Engl J Med. 2020; 382: 2302-15

10. CDC COVID-19 Response Team. Coronavirus disease 2019 in children - United States, February 12 - April 2, 2020. MMWR Morb Mortal Wkly Rep. 2020; 69(14): 422-6.

11. Cai J, Xu J, Lin D et al. A case series of children with 2019 novel coronavirus infection: clinical and epidemiological features. Clin Infect Dis. 2020: ciaa198.

12. Zhang JJ, Dong X, Cao YY et al. Clinical characteristics of 140 patients infected with SARS-CoV-2 in Wuhan, China. Allergy. 2020. http://doi.org/10.1111/all.14238.

13. Pathak EB, Salemi JL, Sobers $N$ et al. COVID-19 in children in the United States: intensive care admissions, estimated total infected, and projected numbers of severe pediatric cases in 2020. J Public Health Manag Pract. 2020; 26(4): 325-33.

14. Tagarro A, Epalza C, Santos $M$ et al. Screening and severity of coronavirus disease 2019 (COVID-19) in Children in Madrid, Spain. JAMA Pediatr. 2020: e201346.

15. Tezer H, Bedir Demirdă̆ T. Novel coronavirus disease (COVID-19) in children. Turk J Med Sci. 2020; 50(SI-1): 592-603.

16. Nathan N, Prevost B, Corvol H. Atypical presentation of COVID-19 in young infants. Lancet. 2020; 395(10235): 1481.

17. See KC, Liew SM, Ng DCE et al. COVID-19: four paediatric cases in Malaysia. Int J Infect Dis. 2020; 94: 125-7.

18. Ludvigsson JF. Systematic review of COVID-19 in children shows milder cases and a better prognosis than adults. Acta Paediatr. 2020; 109(6): 1088-95. 
19. Zheng F, Liao C, Fan QH et al. Clinical characteristics of children with coronavirus disease 2019 in Hubei, China. Curr Med Sci. 2020; 40(2): 275-80.

20. Streng A, Hartmann K, Armann J et al. COVID-19 in hospitalized children and adolescents. Monatsschr Kinderheilkd. 2020. http://10.1007/s00112-020-00919-7.

21. Xing $Y, N i W, W u Q$ et al. Dynamics of faecal SARS-CoV-2 in infected children during the convalescent phase. J Infect. 2020; S0163-4453(20)30177-8.

22. Ong SWX, Tan YK, Chia PY et al. Air, surface environmental, and personal protective equipment contamination by severe acute respiratory syndrome coronavirus 2 (SARS-CoV-2) from a symptomatic patient. JAMA. 2020; 323(16): 1610-12.

23. $\mathrm{Ng} \mathrm{K,} \mathrm{Poon} \mathrm{BH,} \mathrm{Kiat} \mathrm{Puar} \mathrm{TH} \mathrm{et} \mathrm{al.} \mathrm{COVID-19} \mathrm{and} \mathrm{the} \mathrm{risk}$ to health care workers: a case report. Ann Intern Med. 2020; 172(11): 766-7.

24. Abrams EM, Szefler SJ. Managing asthma during coronavirus disease-2019: an example for other chronic conditions in children and adolescents. J Pediatr. 2020; S0022-3476(20)30528- $X$.

25. Zheng XY, Xu YJ, Guan WJ et al. Regional, age and respiratory-secretion-specific prevalence of respiratory viruses associated with asthma exacerbation: a literature review. Arch Virol. 2018; 163(4): 845-53.

26. Brough HA, Kalayci O, Sediva A et al. Managing childhood allergies and immunodeficiencies during respiratory virus epidemics - the 2020 COVID-19 pandemic. A statement from the EAACI-section on pediatrics. Pediatr Allergy Immunol. 2020. http://doi.org/10.1111/pai.13262.

27. Qin C, Zhou L, Hu Z et al. Dysregulation of immune response in patients with COVID-19 in Wuhan, China. Clin Infect Dis. 2020; ciaa248.

28. de Lucena TMC, da Silva Santos AF, de Lima BR et al. Mechanism of inflammatory response in associated comorbidities in COVID-19. Diabetes Metab Syndr. 2020; 14(4): 597-600.

29. Chen J, Zhang ZZ, Chen YK et al. The clinical and immunological features of pediatric COVID-19 patients in China. Genes Dis. 2020; http://doi.org/10.1016/j.gendis.2020.03.008.

30. Ye Q, Wang B, Mao J. The pathogenesis and treatment of the 'Cytokine Storm' in COVID-19. J Infect. 2020; 80(6): 607-13.

31. Jackson DJ, Busse WW, Bacharier LB et al. Association of respiratory allergy, asthma, and expression of the SARS-CoV-2 receptor ACE2. J Allergy Clin Immunol. 2020; S00916749(20)30551-0.

32. Guan WJ, Ni ZY, Hu Y et al. Clinical characteristics of coronavirus disease 2019 in China. N Engl J Med. 2020; 382(18): 1708-20.

33. Report on the epidemiological features of coronavirus disease 2019 (COVID-19) outbreak in the Republic of Korea from Ja- nuary 19 to March 2, 2020. J Korean Med Sci. 2020, 35(10): el12.

34. LuX, Xiang Y, Du H et al. SARS-CoV-2 infection in childrenunderstanding the immune responses and controlling the pandemic. Pediatr Allergy Immunol. 2020. http://doi.org/10.1111/ pai.13267.

35. Shaker MS, Oppenheimer J, Grayson M et al. COVID-19: pandemic contingency planning for the allergy and immunology clinic. J Allergy Clin Immunol Pract. 2020; 8(5): 1477-88.

36. Kowalski ML, Bartuzi Z, Bręborowicz A et al. Stanowisko grupy ekspertów Polskiego Towarzystwa Alergologicznego $w$ sprawie postępowania $u$ chorych na astme $i$ choroby alergiczne w okresie pandemii SARS-CoV-2 (Position statement of expert panel of the Polish Allergology Society on the management of patients with bronchial asthma and allergic diseases during SARS-CoV-2 pandemics). Alergia Astma Immunologia. 2020; 25(1): 2-7.

37. Samoliński B, Majsiak E, Madej M. Strategia diagnozowania alergii BOTTOM-UP $w$ okresie zagrożenia epidemicznego wirusem SARS-CoV-2 powodujacego chorobe COVID-19. Alergia. 2020; 1(83): 16-20.

38. Global Strategy for Asthma Management and Prevention, Global Initiative for Asthma (GINA). Update 2019. https:// ginasthma.org/wp-content/uploads/2019/06/GINA-2019-main-report-June-2019-wms.pdf (Access: 30.05.2020).

39. Global Strategy for Asthma Management and Prevention, Global Initiative for Asthma (GINA). Update 2020. https://ginasthma.org/wp-content/uploads/2020/04/GINA-2020-full -report_final__wms.pdf(Access: 30.05.2020).

40. Yamaya M, Nishimura H, Nadine L et al. Formoterol and budesonide inhibit rhinovirus infection and cytokine production in primary cultures of human tracheal epithelial cells. Respir Investig. 2014; 52(4): 251-60.

41. Yamaya M, Nishimura $H$, Deng X et al. Inhibitory effects of glycopyrronium, formoterol, and budesonide on coronavirus HCoV-229E replication and cytokine production by primary cultures of human nasal and tracheal epithelial cells. Respir Investig. 2020; 58(3): 155-68.

42. Abrams EM, Jong GW, Yang CL. Asthma and COVID-19. CMAJ. 2020; 192(20): E551.

43. Levin M, Ansotegui IJ, Bernstein J et al. Acute asthma management during SARS-CoV2-pandemic 2020. World Allergy Organ J. 2020; 13(5): 100125.

44. Pirożyński M. Terapia wziewna - ze szczególnym uwzględnieniem steroidów $-w$ okresie pandemii COVID-19. Alergia. 2020; 1: 4-6.

45. Kuna P. Postępowanie u chorych na astmę lub POChP $w$ dobie epidemii COVID-19. Terapia. 2020; numer specjalny 01: $17-21$.

46. Emeryk A, Pirożyński M, Mazurek H et al. Polski przewodnik inhalacyjny. Via Medica, Gdańsk 2015. 
47. Doniec Z, Mastalerz-Migas A, Bręborowicz A et al. ReKOMendacje Postępowania $w$ AStmie wczesnodziecięcej dla lekarzy Podstawowej Opieki Zdrowotnej - KOMPAS POZ. Fam Med Prim Care Rev. 2016; 18(2): 181-92.

48. Emeryk A, Pirożyńki M, Mazurek H et al. Stanowisko polskich ekspertów dotyczace nebulizacji $w$ okresie pandemii COVID-19. Terapia. 2020 (in press).

49. Dayal D. We urgently need guidelines for managing COVID-19 in children with comorbidities. Acta Paediatr. 2020. http://doi.org/10.1111/apa.15304.

50. Calvo C, García López-Hortelano M, de Carlos Vicente JC et al. Recommendations on the clinical management of the COVID-19 infection by the "new coronavirus» SARS-CoV2. Spanish Paediatric Association working group. An Pediatr (Barc). 2020; 92(4): 241.

51. Shen KL, Yang YH, Jiang RM et al. Updated diagnosis, treatment and prevention of COVID-19 in children: experts' consensus statement (condensed version of the second edition). World J Pediatr. 2020; 1-8.

52. Şimşek Yavuz S, Ünal S. Antiviral treatment of COVID-19. Turk J Med Sci. 2020; 50(SI-1): 611-9.

53. Dong X, Cao YY, Lu XX et al. Eleven faces of coronavirus disease 2019. Allergy. 2020; 00: 1-11.

54. Bousquet J, Akdis C, Jutel M et al. Intranasal corticosteroids in allergic rhinitis in COVID-19 infected patients: an ARIA-EAACI statement. Allergy. 2020. http://doi.org/ 10.1111/ all.14302.
55. Samoliński B, Arcimowicz M. Polskie standardy leczenia nieżytów nosa (PoSLeNN). Alergol Pol. 2013; S1: 1-167.

56. Emeryk A, Rapiejko P. Alergiczny nieżyt nosa. Lekarz POZ. 2019; 5(2): 165-9.

ORCID

A. Emeryk - ID - http://orcid.org/0000-0003-1853-8696

E. Wawryk-Gawda - ID - http://orcid.org/0000-0001-6914-6735

K. Janeczek - ID - http://orcid.org/0000-0002-8163-873X

Author's contribution:

Emeryk A.: conception, design, literature review, writer, critical review; Wawryk-Gawda E. conception, design, literature review, writer; Janeczek K.: conception, design, literature review, writer.

Copyright: () Medical Education sp. z 0.0. This is an Open Access article distributed under the terms of the Attribution-NonCommercial 4.0 International (CC BY-NC 4.0). License (https://creativecommons.org/licenses/by-nc/4.0/), allowing third parties to copy and redistribute the material in any medium or format and to remix, transform, and build upon the material, provided the original work is properly cited and states its license.

Correspondence

Prof. Andrzej Emeryk, MD, PhD

Department of Pulmonary Diseases and Children Rheumatology,

Children's University Hospital

20-093 Lublin, prof. Antoniego Gębali 6, e-mail: emerykandrzej@gmail.com tel.: (+48) 817185477 